\title{
Evolution Characteristics and Stratigraphic Division of Quaternary Sedimentary in the South Wing of Yangtze River Delta, East China
}

\author{
Ming Wu' ${ }^{1}$ Zhongyang Lin ${ }^{1,2}$ \\ ${ }^{1}$ Zhejiang Institute of Geological Survey, Hangzhou, China \\ ${ }^{2}$ Technical Innovation Center of Agricultural Land Ecological Evaluation and Restoration Project in Plain Area, Ministry of \\ Natural Resources, Hangzhou, China \\ Email: linamdy@163.com
}

How to cite this paper: $\mathrm{Wu}, \mathrm{M}$., \& Lin, $\mathrm{Z}$. Y. (2020). Evolution Characteristics and Stratigraphic Division of Quaternary Sedimentary in the South Wing of Yangtze River Delta, East China. Journal of Geoscience and Environment Protection, 8, 235245.

https://doi.org/10.4236/gep.2020.87014

Received: April 13, 2020

Accepted: July 24, 2020

Published: July 31, 2020

\begin{abstract}
This paper discusses the sporo pollen assemblage, evolution of sedimentary environment, sedimentary facies and the lithotope characteristics revealed by boreholes since pliocene epoch by carrying out ${ }^{14} \mathrm{C}$ dating, sporo pollen and micro-paleontological analysis of sediments in borehole BK01 (depth 237.80 $\mathrm{m}$ ) in the southern flank of the Yangtze River Delta Plain. According to the results of this study, there are 17 species of foraminifera that have been identified as 11 genera, including 16 benthic foraminifera and 1 planktonic foraminifera; 8 species of Ostracoda that have been identified as 8 genera; sporo pollen analysis shows that there are 37 types, including 18 species of woody plant pollen, 11 species of herbaceous plant pollen, 8 species of fern spores, of which, in the sporo pollen assemblage, woody plants have the highest content (about $85.1 \%$ ), ferns spores have about $8.7 \%$, and herbaceous plants have only $6.3 \%$. Sedimentary environment records can be divided into 18 sporo pollen assemblage zones according to borehole lithology, sporo pollen assemblage and micropaleontology analysis. The results show that the BK01 bore strata from bottom to top can be divided into carbonaceous mudstone (Ech), Jiaxing Formation $\left(\mathrm{N}-\mathrm{Qp}_{1}\right)$ ), Qiangang Formation $\left(\mathrm{Qp}_{2} q\right)$ Dongpu Formation $\left(\mathrm{Qp}_{3} d\right)$, Ningbo Formation $\left(\mathrm{Qp}_{3} n\right)$ and Zhenhai Formation (Qhzh).
\end{abstract}

\section{Keywords}

Quaternary, Sporopollen, Stratum, Sedimentary Environment, Yangtze River Delta 


\section{Introduction}

With the change of global environment increasingly becoming an important issue of concern to the international community, the study of the evolution history of global climate and environment since Pleistocene has attracted much attention of scholars (Huang et al., 2018; Edwards, 2003). The Yangtze River Delta is an alluvial plain before the Yangtze River enters the sea (Su et al., 2017; Chen et al., 2009; Zhao et al., 2015; Liu et al., 2010). Studying the sequence of sedimentary strata in the Yangtze River Delta since Pleistocene is not only of great significance to the study of the development history of sedimentation and the evolution of palaeogeographic environment in the Yangtze River Delta (Wang et al., 2008), but also plays an unique role in studying the formation of alluvial plain and the change of palaeogeographic environment in the Yangtze River Delta in this geographical position on the southern wing of the Yangtze River Delta as a research hotspot in recent years (Fan et al., 2011; Chen et al., 2008; Yu et al., 2016).

At present, it has made a lot of important achievements in the study of the changes of paleoclimate and sea level since the last glacial period in the Hangzhou Bay area (Wang et al., 2008; Li et al., 2011), which not only lays a foundation for the further study of sedimentary characteristics, stratigraphic sequence and paleoenvironment evolution since the Quaternary, especially the Holocene, but also provides a detailed basis for the study of the evolution of the Yangtze River delta plain in the Quaternary (Lin et al., 2019a; Zhang, 2005; Yu et al., 2016; Miao et al., 2016; Liu et al., 2010). However, due to the difficulty of drilling, the depth of boreholes and the limitation of the analysis of borehole sample collection and testing in the previous work, the existing research on the Paleoenvironment of Holocene period is more in-depth (Liu et al., 2007; Liu et al., 2019), while the research on the evolution of sedimentary environment since Pleistocene period in the southern wing of the Yangtze River Delta is relatively few, and there are some bottlenecks such as the lack of high-precision stratigraphic data since Pleistocene.

Through sampling and analysis of high resolution sporo pollen, foraminifera and ostracods in the sediment cores of borehole BK01, this paper studies the evolution characteristics of sedimentary facies and sedimentary environment in the plain area of the Yangtze River Delta, and carries out lithological stratification and stratigraphic division of boreholes by combining isotope dating data, which not only provides evidence for the division and comparison of Quaternary strata in the Yangtze River Delta, but also provides basic information for the further research.

\section{Materials and Methods}

Borehole BK01 (30 44'45"N, $\left.120^{\circ} 53^{\prime} 59^{\prime \prime E}\right)$, located in Daqiao Town, Nanhu District, Jiaxing City (Figure 1), is $237.80 \mathrm{~m}$ deep, of which the part below $236.50 \mathrm{~m}$ is bedrock. This study cuts, flattens and describes the lithology of drilled cores 


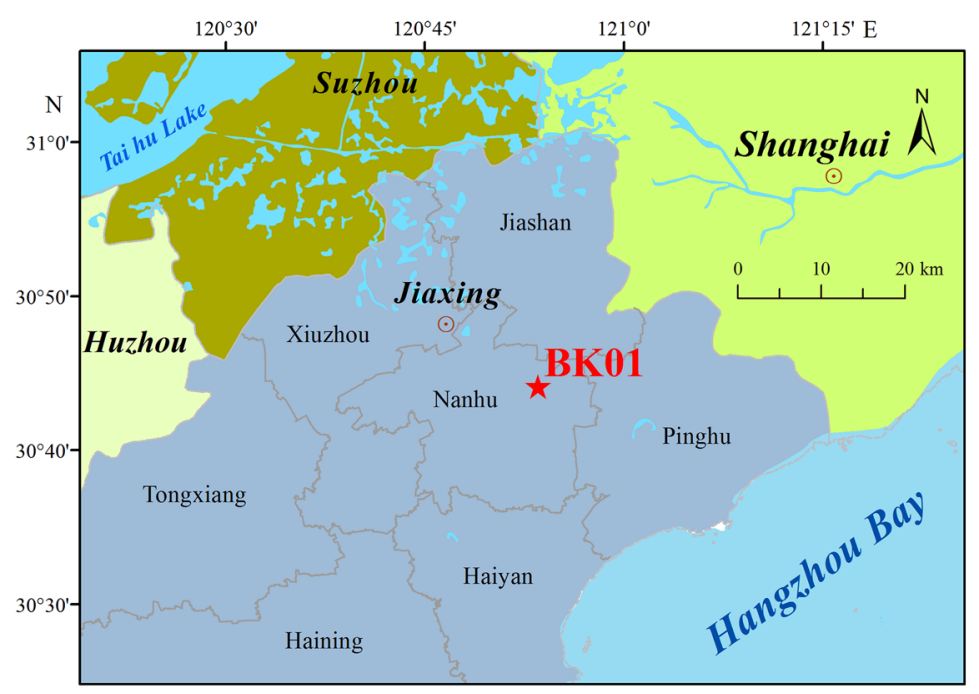

Figure 1. Location of BK01 bore.

from the center along the longitudinal direction, collects 104 samples of micropaleontology (foraminifera, ostracoda) and sporo pollen analysis respectively, 184 samples of grain size analysis, 175 samples of paleomagnetism and 8 samples of photoluminescence dating, with a sampling interval of $1 \mathrm{~m}$.

Micro paleontological analysis includes identification and quantitative statistics of foraminifera and ostracoda species. The specific analysis method is to dry sediment samples below $60^{\circ} \mathrm{C}$, weigh about $50 \mathrm{~g}$ dry samples and add a little $15 \%$ $\mathrm{H}_{2} \mathrm{O}_{2}$ solution, wash the samples with $0.052 \mathrm{~mm}$ pore sieve after dispersal, carry out identification and quantitative statistics of genera and species under Nikon E 200 bio-microscopy after flotation and filtration (calculated with $100 \mathrm{~g}$ dry samples). The process of sporo pollen analysis is to take $50 \mathrm{~g}$ of each sample, extract the sporo pollen flotation material to identify, count and calculate its percentage content under the microscope after acid-alkali treatment and gravity liquid flotation (Zhang, 2005; Tao et al., 2005; Li \& Zhao, 2018; Jia \& Zhang, 2006).

Eight samples of sediment containing carbon chips are packaged in sealed packages for photoluminescence dating (OSL), which is carried out by the conventional methods (Nian et al., 2018; Gao et al., 2019), that is, to take out about $100 \mathrm{~g}$ of unexposed samples in a $1000 \mathrm{ml}$ beaker and soak them in distilled water; first remove organic matter with $30 \%$ hydrogen peroxide, then remove carbonate minerals with $30 \%$ hydrochloric acid, and then wash the suspension to neutrality with distilled water, separate $4-11 \mu \mathrm{m}$ fine-grained mixed minerals according to Stokes theorem, then immerse them in fluosilicic acid for 3 days, remove feldspar and other minerals, purify fine-grained quartz, and evenly precipitate the purified fine-grained quartz sample on stainless steel sheet with $9.7 \mathrm{~mm}$ diameter by ethanol, complete it using Risø TL/OSL-DA-20 thermoluminescence/photoluminescence instrument produced by Risø Laboratory in Denmark.

The Department of Geosciences, Sun Yat-sen University complete sporo pollen analysis and micropaleontology analysis. The Guangzhou Institute of Geo- 
chemistry, Chinese Academy of Sciences is commissioned to complete sediment dating analysis.

\section{Paleoenvironmental Information}

\subsection{Sporo Pollen Assemblage}

The 104 sporo pollen samples from borehole BK01 are identified as 37 sporo pollen types, including 18 woody pollens, 11 herbaceous pollens and 8 fern spores. Among the sporo pollen assemblages, woody plants have the highest content (about $85.1 \%$ ), ferns spores have about $8.7 \%$, and herbaceous plants have only $6.3 \%$. The pollen of coniferous plants is mainly Pinus and Taxodiaceae, and contain a small amount of pollen such as Tsuga. The pollen of broad-leaved plants is mainly Liquidambar, and contains a certain amount of Ulmus, Fagus, Juglans, Quercus and Carpinus. The pollen of herbaceous plants is Cyperaceae and Polygonum, followed by Poaceae and Caryophyllaceae, and a small amount of Liliaceae and Plantago. The pollen of pteridophytes is mainly Polypodiaceae, Trilete spore and Polypodium. It can be divided into 18 sporo pollen assemblage zones according to the changes of sporo pollen types and assemblage characteristics (Figure 2).

P1 (235 - $212 \mathrm{~m})$ : The total concentration of sporo pollen is slightly lower, with an average concentration of 104 grains per gram. The pollen content of pteridophytes is dominant, with an average of $85.5 \%$, among which Polypodiaceae, Trilete spore and Petris are the most abundant; The average pollen content of woody plants is $14.5 \%$, mainly coniferous plants such as Pinus. No herbaceous pollen is found here.

P2 (212 - $166.5 \mathrm{~m})$ : The total concentration of sporo pollen is low, the average concentration is only 9.3 grains per gram. It only find pollen of woody plants, Abies, Mimosa and Penus.

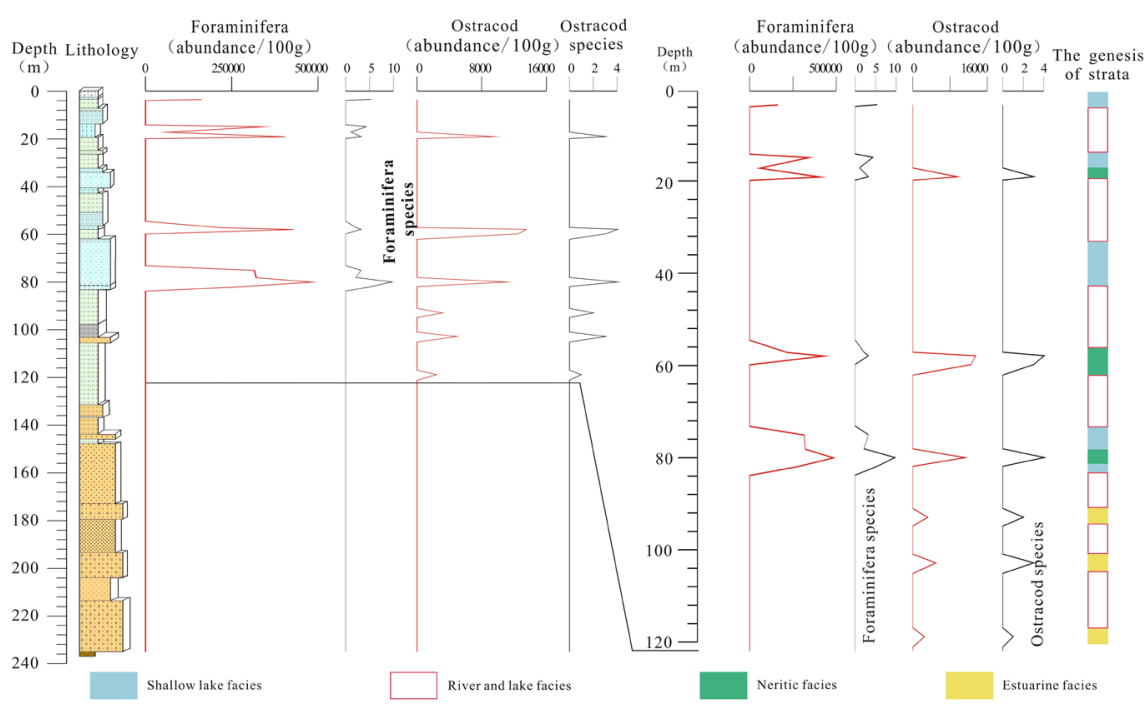

Figure 2. Abundance and differentiation distribution of foraminifera and Ostracod in BK01 and stratigraphic genesis speculation. 
P3 (164.8 - $160 \mathrm{~m})$ : The total concentration of sporo pollen is low, the average concentration is only 58 grains per gram. The pollen content of woody plants is absolutely dominant, with an average content of $79.5 \%$, among which the pollens of conifers such as Pinus and Quercus are the most abundant; The average pollen content of herbaceous plants is $10.2 \%$, mainly of Poaceae plants, while that of ferns is only $10.2 \%$, mainly of Trilete spore.

P4 (157 - $137 \mathrm{~m})$ : The total concentration of sporo pollen is zero.

P5 $(135-131 \mathrm{~m})$ : The total concentration of sporo pollen is low, with an average concentration of 69 grains per gram. All of them are fern pollen. Trilete spore, Polypodiaceae and Cibotium are the most abundant, followed by Pteris.

P6 (129 - $105 \mathrm{~m})$ : The total concentration of sporo pollen is zero.

P7 (103 - $99 \mathrm{~m})$ : The total concentration of sporo pollen is high, with the average concentration of 16,445 grains per gram. The pollen content of woody plants account for the absolute predominance, with an average of $92.9 \%$, of which Pinus and other coniferous plants are the main pollen, followed by Liquidambar and Ulmus; The average pollen content of pteridophytes is $5.7 \%$, mainly Polypodiaceae, while that of herbaceous plants is $1.4 \%$, mainly Polygonum.

P8 (97 - $93 \mathrm{~m})$ : The total concentration of sporo pollen is low, with an average of 102 grains per gram. The average pollen content of woody plants is $65.5 \%$, mainly Liquidambar, followed by Pinus; the average pollen content of ferns is $34.5 \%$, mainly Polypodiaceae, followed by Trilete spores; the pollen content of grass plants is zero.

P9 $(91-80 \mathrm{~m})$ : The total concentration of sporo pollen is high, with an average concentration of 2776 grains per gram. The pollen content of woody plants is absolutely dominant, with an average content of $85.8 \%$, among which Pinus and Abies are the most abundant, followed by Liquidambar, etc. The average pollen content of ferns is $12.8 \%$, mainly Polypodiaceae, and the average pollen content of herbaceous plants is $1.4 \%$, mainly Artemisia.

P10 (78 - $75 \mathrm{~m})$ : The total concentration of sporo pollen is low, with an average concentration of 169 grains per gram. The average pollen content of woody plants is $87.6 \%$, among which Pinus is the most abundant, followed by Liquidambar Formosana; The average pollen content of pteridophytes is $7.0 \%$, mainly Trilete spore, while that of herbaceous plants is $1.1 \%$, mainly Polygonum.

P11 (73 - $69 \mathrm{~m})$ : The total concentration of sporo pollen is higher, with an average concentration of 1039 grains per gram. The pollen content of woody plants is absolutely dominant, with an average content of $94.9 \%$, among which Pinus is the most abundant, followed by Beech, Tsuga, Liquidambar, etc. The average pollen content of pteridophytes is $5.1 \%$, mainly Trilete spore, while that of herbaceous plants is zero.

P12 (66 - $62 \mathrm{~m})$ : The total concentration of sporo pollen is low, with an average concentration of 297 grains per gram. The pollen content of woody plants is absolutely dominant, with an average content of $74.6 \%$, of which Pinus, Hemlock spruce and other coniferous pollen are the main pollen, followed by Beech, 
Liquidambar, etc. The average pollen content of ferns is $23.2 \%$, mainly Trilete spore, while that of herbaceous plants is $2.2 \%$, mainly Cyperaceae.

P13 (60 - $58 \mathrm{~m})$ : The total concentration of sporo pollen is high, with an average concentration of 2847 grains per gram. The pollen content of woody plants is absolutely dominant, with an average content of $79.1 \%$, of which Pinus and Fir are the main coniferous pollen, followed by Beech and Quercus. The average pollen content of pteridophytes is $12.9 \%$, mainly Trilete spore, and that of herbaceous plants is $7.9 \%$, mainly Cyperaceae.

P14 (57 - $42 \mathrm{~m}$ ): The total concentration of sporo pollen is low.

P15 (38.4 - $35 \mathrm{~m})$ : The total concentration of sporo pollen increased slightly, with an average concentration of 190 grains per gram. The pollen content of woody plants accounted for the absolute dominance, with an average content of $73.7 \%$, of which Pinus is the most abundant, followed by Magnolia, etc. The average pollen content of pteridophytes is $17.6 \%$, mainly Polypodiaceae, while that of herbaceous plants is $6.5 \%$, mainly Poaceae.

P16 (32 - $21 \mathrm{~m}$ ): The total concentration of sporo pollen is low, with an average concentration of 37 grains per gram. The pollen content of pteridophytes is absolutely dominant, with an average of $91 \%$, of which Polypodiaceae is the most abundant, followed by Trilete spore, etc. The average pollen content of woody plants is $9 \%$, mainly Magnolia, while that of herbaceous plants is almost zero.

P17 $(20-14 \mathrm{~m})$ : The total concentration of sporo pollen is high with an average concentration of 3247 grains per gram. The average pollen content of woody plants is $74.2 \%$, Juglans and Pinus are the most abundant, followed by Ulmus, Tsuga, Taxodiaceae and Quercus. The average pollen content of herbaceous plants is $15.2 \%$, mainly Cyperaceae, followed by Polygonum and Ranunculus, while that of ferns is $10.6 \%$, mainly Polypodiaceae.

P18 (12.6 - $3.5 \mathrm{~m}$ ): The total concentration of sporo pollen is low, with an average concentration of 109 grains per gram. The pollen content of ferns is absolutely dominant, with an average content of $68.1 \%$, among which Trilete spore and Polypodiaceae are the most abundant, followed by Lygodium, Pteris and Cibotium; The average pollen content of woody plants is $27.5 \%$, mainly Pinus, while that of herbaceous plants is $4.3 \%$, mainly Liliaceae.

\subsection{Micropaleontology}

There are 104 foraminifera samples in borehole BK01, of which 11 genera and 17 species are identified, including 16 benthic foraminifera and one planktonic foraminifera. Each $100 \mathrm{~g}$ sediment contains 0 - 497,489 foraminiferal shells. There are 104 ostracoda samples in borehole BK01, of which 8 genera and 8 species of ostracoda are identified. Each 100 g sediment contains 0 - 125,569 ostracodal shells. The total abundance and species depth distribution of foraminifera and ostracoda are shown in Table 1. Some foraminifera and ostracoda maps are shown in Figure 2. 
Table 1. Total abundance and species distribution of foraminifera and Ostracoda in BK01.

\begin{tabular}{|c|c|c|c|c|c|c|c|}
\hline \multicolumn{4}{|c|}{ Foraminifera } & \multicolumn{4}{|c|}{ ostracoda } \\
\hline $\begin{array}{l}\text { Stratified } \\
\text { position }\end{array}$ & $\begin{array}{l}\text { Depth } \\
\text { (m) }\end{array}$ & $\begin{array}{c}\text { Number } \\
(/ 100 \mathrm{~g})\end{array}$ & Main species & $\begin{array}{l}\text { Stratified } \\
\text { position }\end{array}$ & $\begin{array}{l}\text { Depth } \\
\text { (m) }\end{array}$ & $\begin{array}{c}\text { Number } \\
(/ 100 \mathrm{~g})\end{array}$ & Main species \\
\hline $\mathrm{F} 1$ & $82-75$ & $1876-497,489$ & $\begin{array}{l}\text { Ammonia, } \\
\text { Cribrononion and } \\
\text { Elphidium }\end{array}$ & & & & $\begin{array}{l}\text { Sinocytheridea impressa and } \\
\text { Neosinocythere elongate, }\end{array}$ \\
\hline $\mathrm{F} 2$ & $58-57$ & $384-109,354$ & $\begin{array}{l}\text { Ammonia beccar II } \\
\text { and Cribrononion } \\
\text { subincertum }\end{array}$ & $\mathrm{O} 1$ & 80 & 7483 & $\begin{array}{l}\text { Sinocytheridea impressa, } \\
\text { Sinocythere sinensis and } \\
\text { Stigmatocythere bona }\end{array}$ \\
\hline F3 & $19-15$ & $5-58,321$ & $\begin{array}{l}\text { Ammonia beccar II } \\
\text { and Cribrononion } \\
\text { subincertum }\end{array}$ & $\mathrm{O} 2$ & 58 & 125569 & $\begin{array}{l}\text { Sinocytheridea impressa, } \\
\text { Neomonoceratina dongtaiensis, } \\
\text { Loxoconcha ocellata }\end{array}$ \\
\hline F4 & 3.5 & 83 & $\begin{array}{l}\text { Ammonia and } \\
\text { Elphidium }\end{array}$ & $\mathrm{O} 3$ & 19 & 1890 & $\begin{array}{l}\text { Sinocytheridea impressa, } \\
\text { Loxoconcha ocellata, } \\
\text { Bicorncythere leizhouensisa }\end{array}$ \\
\hline
\end{tabular}

\subsection{Chronological Sequence}

The data of relevant ages measured by OSL method are shown in Table 2. The OSL ages at $24.0 \mathrm{~m}, 29.0 \mathrm{~m}$ and $59.0 \mathrm{~m}$ are $60.5 \pm 3.3 \mathrm{ka}, 74.8 \pm 3.8 \mathrm{ka}$ and 120.6 $\pm 8.9 \mathrm{ka}$, respectively. And the strata at that time belong to the Middle Pleistocene. In addition, OSL ages at hole depths of $108.5 \mathrm{~m}, 129.0 \mathrm{~m}$ and $138.2 \mathrm{~m}$ are all over $150 \mathrm{ka}$.

\section{The Division of Quaternary Strata}

The lithological stratification and stratigraphic division of borehole BK01 are shown in Figure 3. Based on the lithological stratification characteristics and the division of stratigraphic units in the study area (Qi et al., 2017; Lin et al., 2019b), the borehole are Ech (Ech, 236.5 - $237.8 \mathrm{~m})$, and N-Q $p_{1} j, \mathrm{Q} p_{2} q, \mathrm{Q} p_{3} d, \mathrm{Q} p_{3} n$, and Qh $z h$ since early Pleistocene from bottom to top.

$\mathrm{N}-\mathrm{Qp}_{1}$ j: its hole depth is exposed from 147.0 to $236.5 \mathrm{~m}$. Among them, 147.0 $148.3 \mathrm{~m}$ is the al- $\mathrm{N}-\mathrm{Qp}_{1} j_{3}$, with a thickness of $1.3 \mathrm{~m}$, dominated by sub-clay and high content of iron and manganese; $148.3-205.4 \mathrm{~m}$ is the $a /\left(\mathrm{p}_{1}\right) \mathrm{N}-\mathrm{Q} p_{1} j_{3}$, with a thickness of $57.1 \mathrm{~m}$, and the lithology mainly occurs alternately in medium sand, silt and sub-clay, medium coarse sand and gravel sand. $205.4-236.5 \mathrm{~m}$ is the $\mathrm{al}(\mathrm{pl}) \mathrm{N}-\mathrm{Qp}_{1} \dot{2}_{2}$, with a thickness of $31.1 \mathrm{~m}$, and the lithology is dominated by fine sand and gravel.

$\mathrm{Qp}_{2} q$ : whose hole depth is exposed from $84.0 \mathrm{~m}$ to $147.0 \mathrm{~m}$, is marked by hard soil, which is divided into two sections with a thickness of 63.0 M. $84.0-106.3 \mathrm{~m}$ is the $\mathrm{Qp}_{2} q_{2}$ of alluvial lake, marsh and alluvial origin, with a thickness of $22.3 \mathrm{~m}$, mainly clayey soil and sub-sandy soil. 106.3 - $147.0 \mathrm{~m}$ is the $\mathrm{Qp}_{2} q_{1}$, which is formed by alluvial lake and marsh deposits, with a thickness of $40.7 \mathrm{~m}$; 106.3 $132.4 \mathrm{~m}$ is the clayey soil layer with more iron and manganese oxides and more fine silt particles in part; $132.4-137.8 \mathrm{~m}$ is the clayey soil and sub-sandy soil with developed bedding and partly contains semi-carbonated plant residues; 

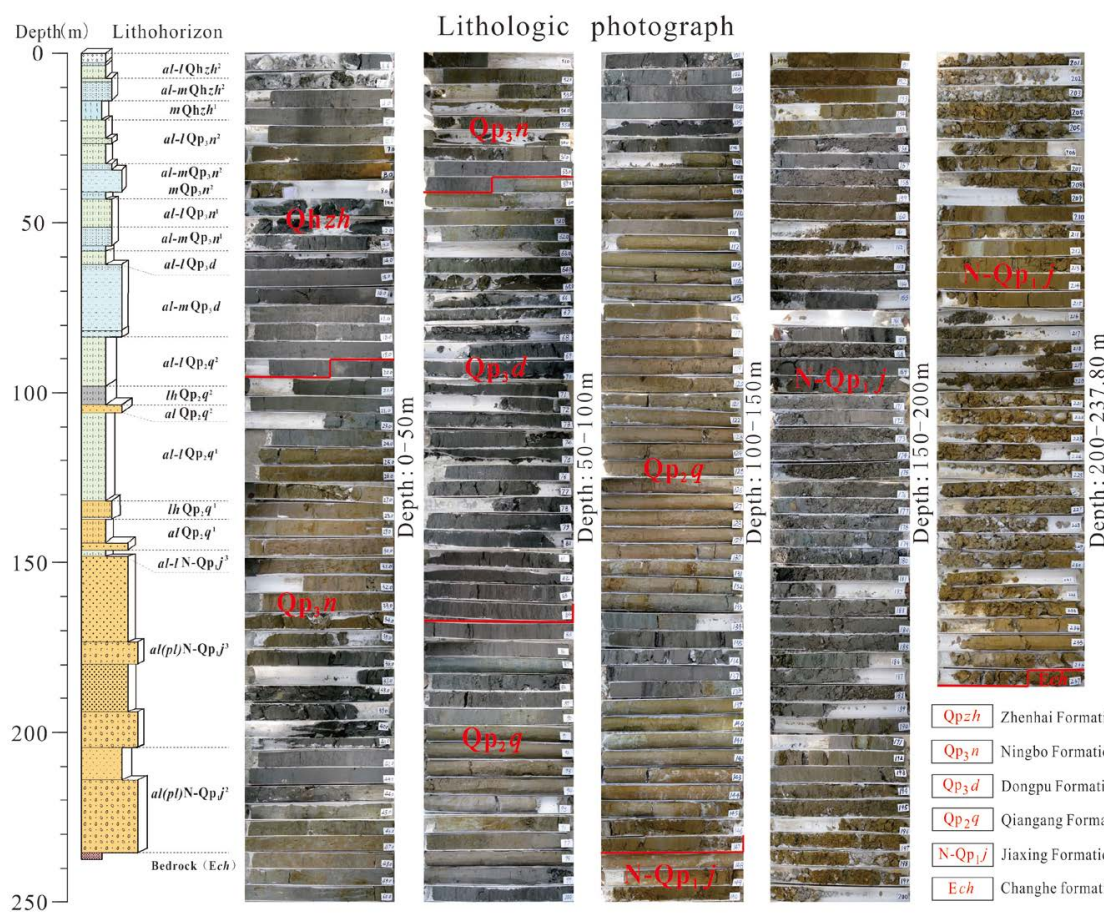

Qp $2 h$ Zhenhai Formation

$Q p_{3} n$ Ningbo Formation

$Q_{p_{3} d}$ Dongpu Formation

$\mathrm{QP}_{2} \mathrm{q}$ Qiangang Formation

N-Qp,$]_{\text {J }}$ Jiaxing Fornation

Figure 3. Lithology stratification and stratigraphic division of BK01.

Table 2. OSL dating results of BK01.

\begin{tabular}{ccccc}
\hline Sample Number & Depth $(\mathrm{m})$ & De $(\mathrm{Gy})$ & DoesRate $(\mathrm{Gy} / \mathrm{ka})$ & Age $(\mathrm{ka})$ \\
\hline BK01-R1 & 24.0 & 151.3 & $2.56 \pm 0.09$ & $60.5 \pm 3.3$ \\
BK01-R2 & 29.0 & 192.2 & $2.57 \pm 0.11$ & $74.8 \pm 3.8$ \\
BK01-R4 & 59.0 & 314.8 & $2.61 \pm 0.12$ & $120.6 \pm 8.9$ \\
BK01-R6 & 90.2 & 386.7 & $2.71 \pm 0.11$ & $142.7 \pm 9.6$ \\
BK01-R7 & 98.0 & $>550$ & $3.65 \pm 0.07$ & $>150$ \\
BK01-R8 & 108.5 & $>550$ & $3.53 \pm 0.12$ & $>150$ \\
BK01-R9 & 129.0 & $>550$ & $3.71 \pm 0.13$ & $>150$ \\
BK01-R10 & 138.2 & $>550$ & $3.81 \pm 0.09$ & $>150$ \\
\hline
\end{tabular}

$137.8-147.0 \mathrm{~m}$ is a sub-clay and medium sand layer with slightly bedding and contains more ferromanganese oxides.

$\mathrm{Qp}_{3}$ d: whose hole depth is exposed from 58.5 to $84.0 \mathrm{~m}$, is marked by hard soil layer with a thickness of $25.5 \mathrm{~m} .58 .5-62.5 \mathrm{~m}$ is $\mathrm{Qp}_{3} d$ of alluvial-lacustrine origin, with a thickness of $4.0 \mathrm{~m}$, mainly the clayey soil. The grains in the lower part are coarser and contain more ferromanganese oxides and calcareous argillaceous nodules. 62.5 - $84.0 \mathrm{~m}$ is the $\mathrm{Qp}_{3} d$ of alluvial-marine origin, with a thickness of $21.5 \mathrm{~m}$, which is mainly composed of silt layer with thin sub-sandy soil.

$\mathrm{Qp}_{3} n$ : whose hole depth is exposed from 19.6 to $58.5 \mathrm{~m}$, is marked by hard soil. The main sediments are clayey soil, clayey soil with sub-sandy soil and sub-sandy soil of alluvial lake, marine and alluvial sub-clay, with a thickness of 38.9 m. 19.6 - $43.1 \mathrm{~m}$ is the $\mathrm{Qp}_{3} n_{2}$ of alluvial-lacustrine, alluvial-marine and ma- 
rine origin, with a thickness of $23.5 \mathrm{~m}$, mainly clayey soil, sub-sandy soil with silt layer, iron-manganese oxide and calcareous nodules. 43.1 - $58.5 \mathrm{~m}$ is the $\mathrm{Qp}_{3} n_{1}$ of alluvial and marine origin, with a thickness of $15.4 \mathrm{~m}$, mainly composed of clayey soil, clayey soil with sub-sandy soil. $43.1-51.4 \mathrm{~m}$ is the alluvial lake origin, which contains more ferromanganese oxides and shows slightly stratification locally. 51.4 - $58.5 \mathrm{~m}$ is mainly the sub-sandy soil and the clayey soil with alluvial and thin layers of marine sediments, partially silt, wormholes and more shell fragments can be seen in the marine layer.

Qh $z h$ : whose hole depth is exposed from 0 to $19.6 \mathrm{~m} .0$ - $3.6 \mathrm{~m}$ is the $\mathrm{Qh} z h_{2}$, which is mainly composed of clayey soil layer of miscellaneous fill and alluvial Lake origin, with a thickness of $3.6 \mathrm{~m} .3 .6-19.6 \mathrm{~m}$ is the $\mathrm{Qh} z h_{1}$, its lower part is silty clay. $3.6-8.5 \mathrm{~m}$ is the $\mathrm{Qh} z h_{1}$ of alluvial-lacustrine origin, with a thickness of $4.9 \mathrm{~m}$ and mainly clayey soil. $8.5-14.0 \mathrm{~m}$ is alluvial-marine origin, with a thickness of $5.5 \mathrm{~m}$, mainly composed of clayey soil with silty clay. $14.0-19.6 \mathrm{~m}$ is marine origin, with a thickness of $5.6 \mathrm{~m}$ and mainly silty loam.

\section{Conclusion}

1) In this borehole, the ages of the photoluminescence strata at depths of 24.0 $\mathrm{m}, 29.0 \mathrm{~m}$ and $59.0 \mathrm{~m}$ are $60.5 \pm 3.3 \mathrm{ka}, 74.8 \pm 3.8 \mathrm{ka}$ and $120.6 \pm 8.9 \mathrm{ka}$, respectively, with the strata age of the Late Pleistocene; The age of photoluminescence strata at depths of $90.2 \mathrm{~m}$ is $142.7 \pm 9.6 \mathrm{ka}$, while that in the depths of $108.5 \mathrm{~m}$, $129.0 \mathrm{~m}$ and $138.2 \mathrm{~m}$ is more than $150 \mathrm{ka}$.

2) The record of sedimentary environment of borehole BK01 can be divided into 18 sporo pollen zones. The early Pleistocene corresponds to the sporo pollen P1 - P3 zones and the early P4 zone. The middle Pleistocene corresponds to the late stage of the sporo pollen P4 zone and the P5 - P9 zones. The late Pleistocene corresponds to the sporo pollen P10 - P16 zones. The Holocene is the tidal flat facies deposited in the $\mathrm{Qh} z h_{1}$ in the early stage and the fluvial and lacustrine facies deposited in the $\mathrm{Qh} z h_{1}$ in the late stage.

\section{Acknowledgements}

This research was funded by Project of China Geological Survey (1212011220008, 1212011220538). The anonymous reviewers, Dr. Maosong Ye and Xudong Zhao provided valuable suggestions and comments on the manuscript, which is greatly appreciated.

\section{Conflicts of Interest}

The authors declare no conflicts of interest regarding the publication of this paper.

\section{References}

Chen, J., Li, X., Wang, Z., \& Chen, Z. (2009). Paleoclimate and Sea Level Fluctuations in Shanghai Region: Sporo-Pollen Implications during the Past 120000 Years. Marine Sciences, 32, 68-73. (in Chinese with English Abstract). 
http://qdhys.ijournal.cn/hykx/ch/reader/view abstract.aspx?file no=20090214\&flag=1

Chen, Q., Li, C., Li, P., Liu, B., \& Sun, H. (2008). Late Quaternary Palaeosols in the Yangtze Delta, China, and Their Palaeoenvironmental Implications. Geomorphology, 100, 465-483. https://doi.org/10.1016/j.geomorph.2008.01.015

Edwards, G. N. (2003). Ichnotaxonomy, Origin, and Paleoenvironment of Quaternary Insect Cells from Fuerteventura, Canary Islands, Spain. Journal of the Kansas Entomological Society, 76, 320-327.

Fan, D., Qi, H., Sun, X., Liu, Y., \& Yang, Z. (2011). Annual Lamination and Its Sedimentary Implications in the Yangtze River Delta Inferred from High-Resolution Biogenic Silica and Sensitive Grain-Size Records. Continental Shelf Research, 31, 129-137. https://doi.org/10.1016/j.csr.2010.12.001

Gao, L., Long, H., Zhang, P., Tamura, T., Feng, W., \& Mei, Q. (2019). The Sedimentary Evolution of Yangtze River Delta since MIS3: A New Chronology Evidence Revealed by OSL Dating. Quaternary Geochronology, 49, 153-158.

https://doi.org/10.1016/j.quageo.2018.03.010

Huang, X., Liang, K., Xia, Z., Zhang, S., Lin, J., Ma, S., \& Huo, Z. (2018). The Sedimentary Characteristics of Upper Pleistocene and Its Palaeo-Environmental Records in Northern Beibu Gulf . Quaternary Sciences, 38, 454-471. (in Chinese with English Abstract).

Jia, L., \& Zhang, Y. (2006). Studies on Palynological Assemblages and Paleoenvironment of Late Quaternary in the East Margin of the Changjiang (Yangtze) River Delta. Acta Micropalaeontologica Sinica, 23, 70-76. (in Chinese with English Abstract).

Li, B., Wei, Z., Li, X., He, Z., Zhang, K., \& Wang, Z. (2011). Records from Quaternary Sediment and Palaeo-Environment in the Yangtze River Delta. Quaternary Sciences, 31, 316-328. (in Chinese with English Abstract).

Li, Q., \& Zhao, Y. (2018). Quantitative Methods and Progress of Paleo-Floristic Diversity Reconstruction Based on Pollen Assemblages. Quaternary Sciences, 38, 821-829. (in Chinese with English Abstract).

Lin, Z., Jin, X., Guan, M., Pan, S., \& Zhao, X. (2019a). Stratigraphic Division and Paleoenvironment Evolution in the Southern Yangtze River Delta Plain since the Pliocene. Earth and Environment, 47, 464-476.

Lin, Z., Jin, X., Guan, M., Zhao, X., Pan, S., \& Long, Z. (2019b). Quaternary Sedimentary Sequence of the Southern Yangtze River Delta and Its Coupling with Paleoenvironmental Evolution. Science Technology and Engineering, 19, 15-24.

http://www.stae.com.cn/ch/reader/view abstract.aspx?file no $=1810631 \&$ flag $=1$

Liu, J., Saito, Y., Kong, X., Wang, H., Xiang, L., Wen, C., \& Nakashima, R. (2010). Sedimentary Record of Environmental Evolution off the Yangtze River Estuary, East China Sea, during the Last $\sim 13,000$ Years, with Special Reference to the Influence of the Yellow River on the Yangtze River Delta during the Last 600 Years. Quaternary Science Reviews, 29, 2424-2438. https://doi.org/10.1016/j.quascirev.2010.06.016

Liu, J., Zhao, S., Cheng, J., Bao, J., \& Yin, G. (2007). A Study of Vegetation and Climate Evolution since the Holocene near the Banks of the Qiangtang River in Hangzhou Bay. Earth Science Frontiers, 14, 235-245. (in Chinese with English Abstract).

Liu, Y., Deng, B., Du, J., Zhang, G., \& Hou, L. (2019). Nutrient Burial and Environmental Changes in the Yangtze Delta in Response to Recent River Basin Human Activities. Environmental Pollution, 249, 225-235. https://doi.org/10.1016/j.envpol.2019.03.030

Miao, W., Li, S., Fen, J., Gao, L., \& Jian, E. (2016). Stratigraphic Division of NB5 Core in the Yangtze Delta Area and Its Environmental Change Information. Geology in China, 6, 2022-2035. (in Chinese with English Abstract).

Nian, X., Zhang, W., Wang, Z., Sun, Q., Chen, J., Chen, Z., \& Hutchinson, S. M. (2018). 
The Chronology of a Sediment Core from Incised Valley of the Yangtze River Delta: Comparative OSL and AMS 14 C Dating. Marine Geology, 395, 320-330.

https://doi.org/10.1016/j.margeo.2017.11.008

Qi, L., Qiao, Y., Li, Y., Wang, Y., Peng, S., He, Z., Yang, S., Han, C., \& Zhang, X. (2017). Intensification of the East Asian Monsoon in Southern China at about 300-400 kaBP Inferred from Eolian Deposits in the Middle-Lower Reaches of the Yangtze River. Acta Geologica Sinica (English Edition), 91, 1095-1108.

https://doi.org/10.1111/1755-6724.13326

Su, J., Fan, D., Leng, W., Chen, L., \& Yin, P. (2017). Postglacial Sequence Stratigraphy and Sedimentary Environment Evolution of the Yangtze River Subaqueous Delta. Journal of Palaeogeography, 19, 541-556. (in Chinese with English Abstract).

Tao, J., Chen, M., \& Xu, S. (2005). A Holocene Environmental Record from the Southern Yangtze River Delta, Eastern China. Palaeogeography, Palaeoclimatology, Palaeoecology, 230, 204-229. https://doi.org/10.1016/j.palaeo.2005.07.015

Wang, Z., Zhang, D., Li, X., Tao, S., \& Xie, Y. (2008). Magnetic Properties and Relevant Minerals of Late Cenozoic Sediments in the Yangtze River Delta and Their Implications. Geology in China, 35, 670-682. (in Chinese with English Abstract).

Yu, J., Lao, J., Jiang, R., Zeng, J., Peng, B., Ma, X., Zhao, L., \& Yang, Z. (2016). Reconstruction of the Late Quaternary Palaeoenvironment on the North Wing of Yangtze River Delta, Based on Comparative Study of the Multistratigraphies. Geological Bulletin of China, 35, 1692-1704. (in Chinese with English Abstract).

Zhang, Y. (2005). Studies on Sporo-Pollen and Environment of Late Quaternary on the Front Edge of Changjiang River Delta. Acta Oceanologica Sinica, 27, 82-87. (in Chinese with English Abstract).

Zhao, Y., Wang, Z., Wu, X., Li, L., Zhan, Q., \& Chen, T. (2015). Grain Size Distribution of Modern Tidal Flat Sediments at the Yangtze River Mouth and Its Application to Identification of Sedimentary Facies. Journal of Palaeogeography, 17, 405-416. (in Chinese with English Abstract). 